\title{
How Does Green Technology Innovation Affect Urbanization? An Empirical Study from Provinces of China
}

\section{Yingzhi Xu ( $\nabla$ xuyingzhi315@163.com )}

Southeast University https://orcid.org/0000-0002-7720-2714

\section{Ruijie Zhang}

Southeast University

\section{Xiaomin Fan}

Southeast University

\section{Qiutong Wang}

Southeast University

\section{Research Article}

Keywords: Green technology innovation, Urbanization, Impact mechanism, Mediating effect, Feasible Generalized Least Squares, China

Posted Date: September 13th, 2021

DOI: https://doi.org/10.21203/rs.3.rs-789283/v1

License: (c) (i) This work is licensed under a Creative Commons Attribution 4.0 International License. Read Full License 


\section{Abstract}

This paper investigates the impact of green technology innovation on urbanization using the panel data for 30 Chinese provinces during 2005-2016. First, using the panel Feasible Generalized Least Squares (FGLS) estimation method, we analyze the direct impact of green technology innovation on urbanization and its three dimensions, namely population urbanization, industrial urbanization and ecological urbanization. Results show that green technology innovation has significantly promoted the development of urbanization, particularly ecological urbanization. Then, we examine the indirect impact of green technology innovation on urbanization applying the mediating effect method. It is concluded that green technology innovation can indirectly affect urbanization through foreign investment effect, energy consumption effect and informatization development effect, while the mediating role of industrial structure optimization effect is not significant. Finally, we propose several recommendations in terms of innovative talents introduction, industrial upgrading, and smart city construction to better promote China's urbanization through green technology innovation.

\section{Introduction}

Urbanization is an essential driving force for economic growth and industrialization (Moomaw and Shatter 1996; Yang et al. 2017). According to United Nations (2018), 68\% of the world's population will live in cities in 2050. As the largest developing country in the world, China's urbanization process has entered a stage of rapid development since the late 1970s. The relevant data show that China's percentage of permanent urban residents increases from $17.9 \%$ of the population in 1978 to $60.60 \%$ in 2019 , with an average annual increase of 1.04 percentage point. Recent studies indicate that urbanization has played a significant role in China's rapid economic growth by accelerating the accumulation of human capital and the upgrade of industrial structure (Lin et al. 2013; Shen and Jiang 2007). However, there are increasing arguments that rapid urbanization is a major threat to the sustainable development in some countries (Cohen 2006; Cobbinah et al. 2015a). According to Cobbinah et al. (2015b), rapid and unplanned urbanization is demographically driven and occurs in the absence of economic and environmental benefits.

China is now exhibiting nearly all the expected consequences of rapid urbanization, such as unbalanced regional development, excessive land consumption and environmental pollution (Liang et al. 2019; Kuang et al. 2020). The report of the 19th National Congress of the Communist Party of China has pointed out that high-quality urbanization is becoming a new requirement and trend of China's future economic development. That is, the transformation from rural to urban in terms of industrial support, living environment and social security should be the main focus of urbanization to maintain a coordinated development of economy, society and environment, not just the increase in the proportion of urban population and the expansion of urban area (Li 2012). However, it is obvious that the inertia of the extensive model of China's urbanization development is still huge, and the hard constraints of the pathlocking effect are difficult to change in a short time. 
Facing the dilemma that the rapid development of urbanization at the expense of environment damage, green technology innovation, which is characterized by sustainability and innovation, is emerging as an ideal solution to address the thorny problems (Wan and Huang 2004). Green technology innovation can lead to the sustainable development of environment through product innovation (Oltra and Saint 2009), thus bring remarkable environmental benefits, rather than merely easing environmental burden (Driessen et al. 2013). Current studies have discussed the relationship between green technology innovation and urbanization at both national and provincial levels (Chen and Ding 2015; Xu et al. 2020). In brief, the relationship between green technology innovation and urbanization is not a simple linear. On one hand, as an input of production resources, green technology innovation brings direct benefits through the transformation of technological achievements, which directly promotes the development of urbanization. On the other hand, green technology innovation plays an indirect role in the development of urbanization by optimizing industrial structure and upgrading energy consumption structure.

However, few empirical researches explored the impact mechanism of green technology innovation on urbanization. Therefore, this paper attempts to complement previous studies by analyzing the direct and indirect effect of green technology innovation on urbanization based on the panel data of 30 provinces in China during the period from 2005 to 2016. Specifically, we firstly investigate the direct impact of green technology innovation on urbanization based on the panel Feasible Generalized Least Squares (FGLS) estimation method. Secondly, we subdivide urbanization into population urbanization, industrial urbanization and ecological urbanization. The impacts of green technology innovation on these dimensions of urbanization are further explored. Thirdly, considering the indirect channel through which green technology innovation affects urbanization, we apply the mediating effect method to examine the indirect effect of green technology innovation on urbanization.

The remainder of this paper is organized as follows. Section 2 provides the literature review. Section 3 describes the mechanism of green technology innovation affecting urbanization, and details the methodology and data description. Section 4 shows the results and discussion of the empirical analysis. Section 5 proposes the conclusions and policy implications.

\section{Literature Review}

Characterized by floating population and urban land expansion (Luo et al. 2018), urbanization is the trend of demographic and economic transformation in developing countries, particularly in Asia and Africa (Montgomery 2008). Krey et al. (2012) pointed out that the process of urbanization has been shown to be important for economic development, particularly in developing countries. According to Song et al (2018), urbanization has become a vital engine of economic growth. Rapid urbanization, however, may be developed at the expense of economy and environmental problems. The rapid growth of population in urban has put significant stress on environmental security, because it may not only lead to a reduced percapita access to subsistence resources but a decline in the overall supply of certain resources (Buhaug and Urdal 2013). Meanwhile, widening the gap between urban and rural areas, rapid urbanization has brought threats to both rural and urban livelihoods and well-being (Yuan et al. 2018). 
In the era of knowledge economy, relying on Information and Communication Technologies (ICTs) to optimize urban governance is an effective way to achieve sustainable development. The existing literature on the relationship between technology innovation and urbanization mainly includes three aspects: First, technology innovation plays a significant role in promoting the development of urbanization. Bettencourt el al. (2007) proposed that it is necessary for the implementation of urban sustainable development to shorten the cycle of technology innovation. Zheng (2017) empirically studied the nonlinear influence of technology innovation on urbanization, and concluded that technology innovation has become an important factor driving China's urbanization. Second, urbanization provides necessary basic support for technology innovation, and the agglomeration effect caused by urbanization brings positive externalities to technological progress (Carlino et al. 2017). Qiu (2013) demonstrated that urbanization promotes technology innovation by gathering production factors, inducing effective demand, and accelerating spatial diffusion. Wu et al. (2013) found that urbanization development would reconfigure production factors through the circular and cumulative causation effect of cost management, so as to achieve factor innovation. Third, urbanization development and technology innovation develop in a coordinated way. Gan (2014) proposed that technology innovation is the driving force of urbanization, while urbanization provides a broad platform for technology innovation. Tian et al. (2017) concluded that there is a bidirectional positive relationship between technology innovation and urbanization development, which is gradually optimized in space.

While China's urbanization is developing at an unprecedented speed, a variety of risks and problems have emerged, such as environmental sustainability problem (Liu et al. 2019), excessive land consumption (Kuang et al. 2020), rural decline (Li et al. 2018), and urban-rural inequality (Guo et al. 2018). To maintain the coordinated development of urbanization and human society, the Chinese government has announced that priority should be given to green production and green consumption in the process of urbanization construction. Therefore, the optimal outlet of urbanization development lies in adopting a new technology innovation mode based on the value of sustainable and green development, namely called green technology innovation (Wan and Huang 2004). First proposed by Braun and Wield (1994), green technology innovation basically refers to a general term for technologies, processes and products that follow ecological principles and ecological economic laws, save resources and energy, avoid, eliminate or mitigate ecological environmental pollution and damage, and minimize ecological negative effects (Peng et al. 2020). Different from traditional technology innovation, green technology innovation is understood as an inclusive concept, intersecting with modern technologies, such as Nanotechnology, Information Technology, or Bioengineering Technology (Lee et al. 2015). Guo et al. (2020) indicated that the purpose of green technology innovation is to tackle integrated sustainable challenges, including environmental damage, irrational industrial structure, livelihood issues and so on, rather than purely environmental problems.

Scholars have explored the relationship between green technology innovation and urbanization. Chen and Ding (2015) found that green technology innovation realizes the intelligent of consumer market through the completion of productization and industrialization, which satisfies the residents' pursuit of highquality life, and thus improving the quality of urbanization. Wu et al. (2019) concluded that green 
technology innovation improves the energy utilization efficiency, thus optimizing the energy consumption structure and promoting the transformation of urbanization from quantity to quality. Liu et al. (2016) proposed that constant green technology innovation can promote the development of information industry, which will penetrate into the fields of municipal, transportation, education, and medical care, so as to optimize the construction of urban infrastructure. Luo et al (2019) pointed out that the increased efficiency of green technology innovation is the main driving force for China's strategic emerging industries and the sustainable development of urbanization.

In summary, existing literature has discussed the impact of green technology innovation on urbanization. However, few studies have empirically analyzed the impact mechanism, including both direct and indirect impact, of green technology innovation on urbanization. Therefore, further research is needed under rather more comprehensive lens.

\section{Impact Mechanism, Methodology And Data Impact mechanism}

\section{The impact mechanism of the direct effect}

The improvement of material value and environmental quality brought by green technology innovation constitutes the important driving force for high-quality development of urbanization. Firstly, green technology innovation promotes the improvement of economy, thus raising residents' income level and living standard, and directly improving residents' living conditions. Secondly, the high-tech industry is further improved based on the marketization of green technology innovation, which is conducive to promote the city-industry integration, and thus gradually perfecting urban functions. Thirdly, green technology innovation is an effective way to control environmental pollution at source through renovating high-pollution industries, which will improve the ecological level.

\section{The impact mechanism of the indirect effect}

Green technology innovation can recombine capital with factors such as knowledge, business model, and institutional environment, which can indirectly affect urbanization.

Industrial structure optimization effect. Green technology innovation promotes the high-end industrial chain development, including front-end technology research and design and back-end service and market (Zhang and Huang 2015). More importantly, urbanization is to guide the upgrading of production and consumption through the advanced industrial structure, so as to achieve high value-added economic growth. Therefore, being an important support for urbanization development, the optimization of industrial structure is bound to lead to the improvement of urbanization (Chenery and Syrquin 1975).

Foreign investment effect. With the in-depth development of China's opening up, the entry of foreign capital has brought a considerable number of employment opportunities and fiscal revenue to China, and 
promoted the development of China's urbanization. Green technology innovation influences the quality of foreign investment by enhancing China's position in the global value chain. High-quality foreign investment flows freely in industrial sectors and regions, thereby further promoting the development of urbanization in coordination, openness and sharing (Sang and Zhang 2018).

Energy consumption effect. The green technological breakthroughs in clean energy exploitation and utilization directly increase the supply and consumption of clean energy, thus improving the energy consumption structure. The optimized energy consumption structure reduces the dependence of urbanization development on fossil energy, which is conducive to eliminate the tail effect of energy consumption in urbanization development and realize the sustainable development of urbanization.

Informatization development effect. Green technology innovation is the dominant factor in informatization development. Informatization development enhances the radiating and driving role of central cities, which is conducive to the coordinated development of urban agglomeration. At present, China's smart city pilot projects have been launched in many cities. It is obvious that informatization development will become an important trend in urbanization development.

The mechanism of green technology innovation affecting urbanization is showed in Fig. 1. This paper is devoted to analyzing both the direct and indirect impact of green technology innovation on urbanization, and we have the following hypotheses:

H1: Green technology innovation has a direct impetus to urbanization development;

$\mathrm{H} 2$ : Green technological innovation has a direct impact on population urbanization, industrial urbanization and ecological urbanization;

H3: Industrial structure optimization, improved foreign investment, energy consumption structure optimization and informatization development play an intermediary role in promoting urbanization through green technology innovation.

\section{Model specification}

This paper aims to study the impact of green technology innovation on urbanization, together with the impact mechanism. We use the panel Feasible Generalized Least Squares (FGLS) estimation method to investigate the direct effect of green technology innovation on urbanization. Meanwhile, the indirect effect of green technology innovation on urbanization is further examined through the mediating effect method.

In order to investigate the direct effect of green technology innovation on urbanization, this paper constructs a regression model as shown in equation (1):

$$
U R B_{i t}=\alpha_{i t}+\beta_{1} G T I_{i t}+\sum \beta_{m} \text { Control }_{i t}+\eta_{i}+\mu_{t}+\varepsilon_{i t}
$$


Where $i$ represents the province and $t$ represents the year. $U R B_{i t}$ represents the level of urbanization, $G T I_{i t}$ represents the level of green technology innovation, Control ${ }_{i t}$ are a series of exogenous control variables, including infrastructure construction (INFRA), education development (EDU), marketization (MARKET), and financial development $(F I M) . \eta_{i}$ and $\mu_{t}$ respectively represent the annual and individual effects, $\varepsilon_{i t}$ is the random disturbance term.

The mechanism of green technology innovation affecting urbanization is further tested applying the mediating effect method. The models as shown in equation (2), (3) and (4) are constructed:

$$
\begin{gathered}
U R B_{i t}=\alpha_{i t}+\beta_{1} \text { GTI I }_{i t}+\sum \beta_{m} \text { Control }_{i t}+\eta_{i}+\mu_{t}+\varepsilon_{i t} \\
M_{i t}=\gamma_{i t}+\delta_{1} \text { GTI }_{i t}+\sum \delta_{m} \text { Control }_{i t}+\eta_{i}+\mu_{t}+\varepsilon_{i t} \\
U R B_{i t}=\sigma_{i t}+\theta_{1} \text { GTI }_{i t}+\rho M_{i t}+\sum \theta_{m} \text { Control }_{i t}+\eta_{i}+\mu_{t}+\varepsilon_{i t}
\end{gathered}
$$

Where $M_{i t}$ represents the mediating variables, including industrial structure optimization (STRU), foreign investment $(F D I)$, energy consumption structure (ESTR) and informatization development (INFOR). Generally speaking, when the parameter $\beta_{1}$ in Eq. (2) is significantly positive, and if the parameter $\delta_{1}$ in Eq. (3) and parameter $\rho$ in Eq. (4) are significantly positive, it indicates that $G T /$ has a positive mediating effect on URB through mediator $M$.

\section{Variable declaration}

Urbanization (URB). The current urbanization of China has entered into a new development stage in which not only the improvement of urbanization rate is required, but also the achievement of economic intensive development, industry optimization, the happiness of people and livable environment. Therefore, the traditional single index can no longer meet the requirement of measure. With reference to $\mathrm{Xu}$ and Wang (2018), the evaluation index system of urbanization level is constructed based on the three principles of urbanization development, namely, people-oriented, city-industry integration and green ecology, and shown in Table 1.

Table 1 Evaluation index system of urbanization. 


\begin{tabular}{|c|c|c|c|}
\hline Target & Criterion & Factor & Indicator \\
\hline \multirow{8}{*}{$\begin{array}{l}\text { Urbanization } \\
\text { development }\end{array}$} & \multirow{3}{*}{$\begin{array}{l}\text { People- } \\
\text { oriented }\end{array}$} & Basic life & Per capita GDP, Average wages of urban staff \\
\hline & & $\begin{array}{l}\text { The guarantee } \\
\text { of people's } \\
\text { livelihood }\end{array}$ & $\begin{array}{l}\text { The proportion of urban endowment insurance } \\
\text { participants, The number of health technicians per } \\
\text { ten thousand people, The proportion of education } \\
\text { expenditure in fiscal expenditure }\end{array}$ \\
\hline & & $\begin{array}{l}\text { Coordinating } \\
\text { urban and } \\
\text { rural } \\
\text { development }\end{array}$ & $\begin{array}{l}\text { Proportion of urban population, Urban and rural } \\
\text { income ratio, Urban and rural consumption ratio }\end{array}$ \\
\hline & \multirow{2}{*}{$\begin{array}{l}\text { City- } \\
\text { industry } \\
\text { integration }\end{array}$} & $\begin{array}{l}\text { Structure } \\
\text { optimization }\end{array}$ & $\begin{array}{l}\text { The proportion of non-agricultural industries, Fixed } \\
\text { investment in high-tech industries }\end{array}$ \\
\hline & & $\begin{array}{l}\text { Quality } \\
\text { improvement }\end{array}$ & $\begin{array}{l}\text { The proportion of urban employment personnel with } \\
\text { college degree or above, Energy consumptions per } \\
\text { GDP, The number of granted patent approval per } 100 \\
\text { million GDP }\end{array}$ \\
\hline & \multirow[t]{3}{*}{$\begin{array}{l}\text { Green } \\
\text { ecology }\end{array}$} & $\begin{array}{l}\text { Environmental } \\
\text { investment }\end{array}$ & Per capita environmental infrastructure investment \\
\hline & & $\begin{array}{l}\text { Urban } \\
\text { landscaping }\end{array}$ & $\begin{array}{l}\text { Per capita public green areas, Coverage rate of urban } \\
\text { green areas }\end{array}$ \\
\hline & & $\begin{array}{l}\text { Pollution } \\
\text { treatment }\end{array}$ & $\begin{array}{l}\text { Comprehensive utilization rate of fixed waste, } \\
\text { Hazard-free treatment rate of household garbage }\end{array}$ \\
\hline
\end{tabular}

This paper uses the improved entropy method to determine the weight of each indicator, and then measures the level of urbanization. The calculation method is as follows:

Firstly, the dimensionless treatment is carried out on each indicator. The formulas for positive and negative indicator are respectively shown as equation (5) and (6):

$\begin{aligned} x_{i j}^{\prime} & =\frac{x_{i j}-\min \left(x_{j}\right)}{\max \left(x_{j}\right)-\min \left(x_{j}\right)} \\ x_{i j}^{\prime} & =\frac{\max \left(x_{j}\right)-x_{i j}}{\max \left(x_{j}\right)-\min \left(x_{j}\right)}\end{aligned}$

Secondly, calculate the proportion of index $x_{i j}$ of index $j$ :

$$
p_{i j}=\frac{x_{i j}}{\sum_{i=1}^{n} x_{i j}}
$$

Thirdly, calculate the information entropy of index $j$ : 
$e_{j}=-\frac{1}{\ln n} \sum_{i=1}^{n}\left(p_{i j} * \ln p_{i j}\right)$

Fourthly, calculate the coefficient of difference of index $j$ :

$$
g_{j}=1-e_{j}
$$

Fifthly, ascertain the weighing of each evaluation indicator:

$$
w_{j}=\frac{g_{j}}{\sum_{j=1}^{m}\left(g_{j}\right)}
$$

Finally, obtain the comprehensive evaluation value of urbanization:

$$
z_{i}=\sum_{j=1}^{m} w_{j} * x_{i j}
$$

Green technology innovation (GTI). The measurement of green technology innovation mainly includes the single index method, evaluation index system method and efficiency measure method (Zhang 2015; Sun et al. 2017). Referring to Luo and Liang (2016), this paper divides the process of green technology innovation into two stages, including green technology development stage and green technology achievement transformation stage, and constructs the input-output evaluation index system of green technology innovation as shown in Table 2. The super-efficiency DEA method is used to measure the level

\begin{tabular}{|c|c|c|}
\hline Stage & $\begin{array}{l}\text { First-class } \\
\text { indicator }\end{array}$ & Second-class indicator \\
\hline \multirow[t]{3}{*}{$\begin{array}{l}\text { Green technology } \\
\text { development }\end{array}$} & R\&D input & $\begin{array}{l}\text { Full-time equivalent of R\&D personnel, Internal expenditure on } \\
\text { R\&D, Expenditure on technology introduction and } \\
\text { transformation, Expenditure on new product development }\end{array}$ \\
\hline & Energy input & Energy intensity \\
\hline & $\begin{array}{l}\text { Intermediate } \\
\text { output }\end{array}$ & Patent application quantity \\
\hline \multirow{2}{*}{$\begin{array}{l}\text { Green technology } \\
\text { achievement } \\
\text { transformation }\end{array}$} & $\begin{array}{l}\text { Desirable } \\
\text { output }\end{array}$ & Sales revenue of new products \\
\hline & $\begin{array}{l}\text { Undesirable } \\
\text { output }\end{array}$ & Carbon emission \\
\hline
\end{tabular}
of green technology innovation.

Table 2 Input-output system of green technology innovation.

Industrial structure optimization (STRU). Referring to Cai and Xu (2017), we use the ratio of the output value of the tertiary industry and the secondary industry to characterize the industrial structure 
optimization effect.

Foreign investment (FDI). In this paper, the effect of foreign investment is measured by the proportion of foreign direct investment in GDP.

Energy consumption structure (ESTR). Increasing the proportion of natural gas consumption has become an important means to promote China's green development of urbanization. Consistent with Xu and Wang (2018), we introduce the proportion of natural gas consumption in total energy consumption to measure the energy consumption effect.

Informatization development (INFOR). This paper uses the per capita sales value of computer, communication and other electronic equipment manufacturing industries to measure the informatization development effect.

Infrastructure construction (INFRA). INFRA is measured by urban road area per capita.

Education development (EDU). EDU is measured by the number of college students per thousand people.

Marketization (MARKET). Referring to Fan et al. (2011), we measure the degree of marketization from the perspectives of the relationship between government and market, the development of non-state-owned economy, the development of product market, the development of market intermediary organization and the legal system environment.

Financial development (FIM). The ratio of the loan balance of financial institutions to GDP is used to measure the level of financial development (Li et al. 2016).

\section{Data sources}

In view of the principle of data availability, due to the lack of statistical data in Tibet, Hong Kong, Macao and Taiwan, this paper selects the remaining 30 provinces in China over 2005-2016 as research sample. The data are mainly collected from the "China Statistical Yearbook", "China Population \& Employment Statistics Yearbook", "China Statistical Yearbook on Science and Technology", "China Statistical Yearbook on Environment" and "China Energy Statistical Yearbook'. The mean value method is used to make up for the missing data of some statistical indicators. Meanwhile, we take 2005 as the base period to deflate the data. Table 3 presents the statistical description of the variables used in our analysis.

Table 3 Statistical description of variables. 


\begin{tabular}{|c|c|c|c|c|c|c|}
\hline $\begin{array}{l}\text { Variable } \\
\text { type }\end{array}$ & $\begin{array}{l}\text { Variable } \\
\text { name }\end{array}$ & Meaning of variable & $\begin{array}{l}\text { Mean } \\
\text { value }\end{array}$ & $\begin{array}{l}\text { Standard } \\
\text { deviation }\end{array}$ & $\begin{array}{l}\text { Minimum } \\
\text { value }\end{array}$ & $\begin{array}{l}\text { Maximum } \\
\text { value }\end{array}$ \\
\hline $\begin{array}{l}\text { Explained } \\
\text { variable }\end{array}$ & URB & Urbanization & 0.4162 & 0.1332 & 0.1389 & 0.8321 \\
\hline $\begin{array}{l}\text { Core } \\
\text { variable }\end{array}$ & $G T I$ & $\begin{array}{l}\text { Green technology } \\
\text { innovation }\end{array}$ & 0.5887 & 0.2903 & 0.1104 & 1.9415 \\
\hline \multirow[t]{4}{*}{$\begin{array}{l}\text { Intervening } \\
\text { variable }\end{array}$} & STRU & $\begin{array}{l}\text { Industrial structure } \\
\text { optimization }\end{array}$ & 1.0309 & 0.2022 & 0.3571 & 1.3298 \\
\hline & $F D I$ & Foreign investment & 4.2359 & 4.6708 & 0.00996 & 22.5732 \\
\hline & ESTR & $\begin{array}{l}\text { Energy consumption } \\
\text { structure }\end{array}$ & 0.0482 & 0.0571 & 0.0002 & 0.3357 \\
\hline & INFOR & $\begin{array}{l}\text { Informatization } \\
\text { development }\end{array}$ & 0.3951 & 0.6565 & .0002 & 2.9691 \\
\hline \multirow[t]{4}{*}{$\begin{array}{l}\text { Control } \\
\text { variable }\end{array}$} & INFRA & $\begin{array}{l}\text { Infrastructure } \\
\text { construction }\end{array}$ & 7.7897 & 2.6622 & 2.7953 & 17.8542 \\
\hline & $E D U$ & $\begin{array}{l}\text { Education } \\
\text { development }\end{array}$ & 23.3722 & 10.1824 & 8.3800 & 68.9700 \\
\hline & MARKET & Marketization & 6.3056 & 1.7813 & 2.5300 & 10.9200 \\
\hline & FIN & $\begin{array}{l}\text { Financial } \\
\text { development }\end{array}$ & 1.1530 & 0.4095 & 0.5372 & 2.5847 \\
\hline
\end{tabular}

\section{Results And Discussion}

\section{The direct effect of green technology innovation on urbanization}

Eq. (1) is estimated in Table 4. Model (1) is the estimation result of only incorporating explanatory variables. Model (2), (3), (4), and (5) are the estimation results controlling infrastructure construction, education development, marketization, and financial development step by step. It is noted that heteroscedasticity and first-order sequence correlation exist among variables through the test of the panel data, so we use the panel Feasible Generalized Least Squares (FGLS) estimation method to improve the robustness in model (6). 
Table 4

Empirical results with the direct effect.

\begin{tabular}{|c|c|c|c|c|c|c|}
\hline & Model(1) & Model(2) & Model(3) & Model(4) & Model(5) & Model(6) \\
\hline \multirow[t]{2}{*}{ GTI } & $0.2655^{\star \star \star}$ & $0.1613^{\star \star \star}$ & $0.1378^{\star \star \star}$ & $0.1255^{\star \star \star}$ & $0.1236^{\star \star \star}$ & $0.0566^{\star \star \star}$ \\
\hline & $(12.34)$ & $(8.53)$ & $(7.75)$ & $(8.48)$ & $(8.39)$ & $(9.52)$ \\
\hline \multirow[t]{2}{*}{ INFRA } & & $0.037^{\star \star \star}$ & $0.0248^{\star \star \star}$ & $0.0134^{\star \star \star}$ & $0.0125^{\star \star \star}$ & $0.0097^{\star \star \star}$ \\
\hline & & (15.17) & $(8.91)$ & $(5.37)$ & $(4.95)$ & $(8.90)$ \\
\hline \multirow[t]{2}{*}{$E D U$} & & & $0.0085^{\star \star \star}$ & $0.0069^{\star \star \star}$ & $0.0072^{\star \star \star}$ & $0.0065^{\star \star \star}$ \\
\hline & & & $(7.51)$ & (12.43) & $(7.51)$ & $(14.10)$ \\
\hline \multirow[t]{2}{*}{ FIN } & & & & $0.1876^{\star \star *}$ & $0.1865^{\star \star \star}$ & $0.0385^{\star \star \star}$ \\
\hline & & & & (12.18) & (12.17) & $(4.79)$ \\
\hline \multirow[t]{2}{*}{ MARKET } & & & & & $0.0082^{\star \star}$ & $0.0067^{\star \star \star}$ \\
\hline & & & & & $(2.19)$ & $(3.86)$ \\
\hline \multirow[t]{2}{*}{ _cons } & $0.2599^{\star \star \star}$ & $0.033^{*}$ & $-0.0576^{\star \star \star}$ & $-0.1390^{\star \star \star}$ & $-0.1890^{\star \star \star}$ & $0.0540^{\star \star \star}$ \\
\hline & $(14.16)$ & $(1.73)$ & $(-2.72)$ & $(-7.40)$ & $(-6.42)$ & $(2.72)$ \\
\hline$N$ & 360 & 360 & 360 & 360 & 360 & 360 \\
\hline Model Selection & $R E$ & $F E$ & $F E$ & $F E$ & $F E$ & FGLS \\
\hline
\end{tabular}

The coefficients of $G T /$ is significantly positive at the $1 \%$ level as shown in the model (1), indicating that the improvement of green technology innovation is helpful to promote urbanization development, which is completely consistent with the expected hypothesis. With successively incorporating control variables, the estimated effects of green technology innovation on urbanization are still significantly positive, which implies that infrastructure construction, education development, marketization, and financial development are effective in promoting urbanization development. Compared with model (5), the estimated coefficients of the FGLS method in the model (6) are quite different, but the significance of each variable remains unchanged.

It's obvious that the coefficient of $G T /$ is larger than any other control variables, indicating that the most effective path to promote urbanization development is to develop green technology innovation. That is to say, government should pay attention to the innovation of green technology in the construction of urbanization. In recent years, China has made great efforts to promote the development of green technology innovation. Specifically, relevant government plans and policies have been continuously introduced, investment in R\&D for green technology innovation has grown steadily, and China's innovation 
environment for green technology has been increasingly optimized. With the late-mover advantage of green technology innovation, China has built numerous urban agglomerations and modern metropolitan areas, and the urbanization rate exceeded $60 \%$ in 2019. China's green technology innovation can promote the green and high-quality development of urbanization by improving the quality of residents' life, reducing pollution emissions and increasing economic effects. Therefore, the Hypothesis 1 is verified.

The coefficients of control variables, including INFRA, EDU, FIN, and MARKET are all significantly positive, indicating that the improvement of the infrastructure construction, education development, financial development, and marketization have significantly promoted the level of urbanization. The possible reasons for this could be that the improved infrastructure construction and marketization improve the efficiency in production and reduce environmental pollution, thus promoting the development of urbanization. What's more, the high-quality development of education and financial industry is conducive to the development of urbanization with "people-oriented" and "city-industry integration".

According to the three principles of urbanization, namely people-oriented, city-industry integration and green ecology, we subdivides urbanization into population urbanization (POPURB), industrial urbanization (STRURB) and ecological urbanization (ECOURB), so as to explore the effect of green technology innovation on these dimensions of urbanization. The results are shown in Table 5. 
Table 5

Empirical results with three dimensions of urbanization.

\begin{tabular}{|c|c|c|c|}
\hline & Population urbanization & Industrial urbanization & Ecological urbanization \\
\hline \multirow[t]{2}{*}{$G T I$} & $0.0349^{* \star \star}$ & $0.0338^{\star \star \star}$ & $0.0950^{\star * \star}$ \\
\hline & $(4.68)$ & $(5.67)$ & $(8.97)$ \\
\hline \multirow[t]{2}{*}{ INFRA } & $0.0114^{\star \star \star}$ & $0.0037^{\star \star \star}$ & $0.0150^{\star \star \star}$ \\
\hline & $(8.38)$ & $(2.73)$ & (8.99) \\
\hline \multirow[t]{2}{*}{$E D U$} & $0.0056^{\star \star \star}$ & $0.0050^{\star \star \star}$ & $0.0040^{\star \star \star}$ \\
\hline & $(8.73)$ & $(9.49)$ & $(4.07)$ \\
\hline \multirow[t]{2}{*}{$F I N$} & $0.0211^{*}$ & $0.0642^{\star \star \star}$ & $0.0524^{\star \star \star}$ \\
\hline & $(1.77)$ & $(4.90)$ & $(4.23)$ \\
\hline \multirow[t]{2}{*}{ MARKET } & $0.0090^{\star \star \star}$ & $0.0120^{\star \star \star}$ & $0.0116^{\star \star \star}$ \\
\hline & (3.18) & $(6.09)$ & $(3.60)$ \\
\hline \multirow[t]{2}{*}{ _cons } & $0.0938^{\star \star \star}$ & -0.0173 & $0.1143^{\star \star \star}$ \\
\hline & $(3.14)$ & $(-1.02)$ & $(2.85)$ \\
\hline$N$ & 360 & 360 & 360 \\
\hline
\end{tabular}

The coefficients of $G T /$ are all significantly positive at the $1 \%$ level, suggesting that the improvement of green technology innovation has significant promoted population urbanization, industrial urbanization and ecological urbanization. The coefficient of green technology innovation on ecological urbanization is the larger than that on population urbanization and industrial urbanization. A possible explanation for this is that green technology innovation aims at environmental friendliness. The innovative technologies play a positive role in reducing resource consumption in the production process, and alleviating the environmental pollution problems caused by urbanization development, thus significantly promoting ecological urbanization. At the same time, due to the improvement of environmental quality and economic growth, green technology innovation improves the livability of cities and increases the happiness of urban residents, which is conducive to promoting population urbanization. Besides, the industrialization and marketization of green technology innovation contribute to the development of hightech industries, thus optimizing the industrial structure. However, the coefficient of green technology innovation on industrial urbanization is the lowest, which may be that the far-flung industrialization process of innovation results leads to the mismatch between urban expansion and industrial upgrading, and then the driving effect of green technology innovation on the city-industry integration of industrial urbanization is still not fully released. To sum up, the Hypothesis 2 is verified. 


\section{The indirect effect of green technology innovation on urbanization}

Based on the scatter diagram, we intuitively investigate the transmission mechanism of green technology innovation to urbanization, as shown in Fig. 2. It is obvious that there is a significantly positive relationship between green technology innovation and urbanization. However, as shown in Fig. 2a), the upgrading of industrial structure does not rise significantly with the improvement of green technology innovation, the same as the relationship between industrial structure optimization and urbanization. Therefore, it is possible that industrial structure optimization plays a weak intermediary role in the impact of green technology innovation on urbanization.

The mechanism of green technology innovation affecting urbanization is examined based on the mediating effect method. We estimate Eqs. (3) and (4) to test the mediating role of industrial structure optimization effect, foreign investment effect, energy consumption structure effect and informatization development effect in the impact of green technology innovation on urbanization. The estimated results of Eq. (3) are presented in the model (1), (3), (5) and (7) in Table 6 respectively, and the estimated results of Eq. (4) are reported in the model (2), (4), (6) and (8) in Table 6 respectively. 
Table 6

Empirical results with the mediating effect method.

\begin{tabular}{|c|c|c|c|c|c|}
\hline & \multicolumn{2}{|c|}{$\begin{array}{l}\text { Industrial structure } \\
\text { optimization effect }\end{array}$} & \multicolumn{3}{|c|}{ Foreign investment effect } \\
\hline & STRU & URB & $F D I$ & & URB \\
\hline & Model (1) & Model (2) & Model (3) & & Model (4) \\
\hline \multirow[t]{2}{*}{ GTI } & 0.0507 & $0.0560^{\star \star \star}$ & $1.4062^{\star \star \star}$ & & $0.0398^{\star \star \star}$ \\
\hline & $(0.79)$ & $(9.18)$ & $(8.50)$ & & $(5.17)$ \\
\hline \multirow[t]{2}{*}{ INFRA } & $0.0123^{*}$ & $0.0098^{\star \star \star}$ & $0.2124^{\star \star \star}$ & & $0.0085^{\star \star \star}$ \\
\hline & $(1.70)$ & $(8.91)$ & $(5.02)$ & & $(8.86)$ \\
\hline \multirow[t]{2}{*}{$E D U$} & $-0.0054^{\star \star \star}$ & $0.0065^{\star \star \star}$ & $0.0595^{\star \star \star}$ & & $0.0064^{\star \star \star}$ \\
\hline & $(-4.16)$ & $(14.25)$ & $(4.95)$ & & $(11.00)$ \\
\hline \multirow[t]{2}{*}{ MARKET } & $-0.0286^{\star \star \star}$ & $0.0070^{\star \star \star}$ & $0.7684^{\star \star \star}$ & & 0.0034 \\
\hline & $(-2.83)$ & $(4.13)$ & $(13.58)$ & & $(1.14)$ \\
\hline \multirow[t]{2}{*}{ FIN } & $0.1558^{\star \star \star}$ & $0.0384^{\star \star \star}$ & $-0.7781^{\star *}$ & & $0.0549^{\star \star \star}$ \\
\hline & $(4.38)$ & $(4.78)$ & $(-2.34)$ & & $(5.14)$ \\
\hline \multirow[t]{2}{*}{ STRU } & & 0.0017 & & & \\
\hline & & $(1.29)$ & & & \\
\hline \multirow[t]{2}{*}{$F D I$} & & & & & $0.0029^{\star \star}$ \\
\hline & & & & & $(2.55)$ \\
\hline \multicolumn{6}{|l|}{ ESTR } \\
\hline \multicolumn{6}{|l|}{ INFOR } \\
\hline \multirow[t]{2}{*}{ _cons } & $1.0024^{\star \star \star}$ & $0.0516^{\star \star \star}$ & $-3.3957^{\star \star \star}$ & & $0.0579^{\star *}$ \\
\hline & $(10.93)$ & $(2.62)$ & $(-5.15)$ & & $(2.45)$ \\
\hline \multirow[t]{4}{*}{$N$} & 360 & 360 & 360 & & 360 \\
\hline & \multicolumn{2}{|c|}{ Energy consumption effect } & \multicolumn{2}{|c|}{$\begin{array}{l}\text { Informatization } \\
\text { development effect }\end{array}$} & $\begin{array}{l}\text { Four intervening variables } \\
\text { included }\end{array}$ \\
\hline & ESTR & URB & INFOR & $U R B$ & $U R B$ \\
\hline & Model (5) & Model (6) & Model (7) & Model (8) & Model (9) \\
\hline
\end{tabular}

Note* * ** and *** represent significance at $10 \%, 5 \%$, and $1 \%$ level, respectively; the $t$-test is shown in 0 


\begin{tabular}{|c|c|c|c|c|c|}
\hline & \multicolumn{2}{|c|}{$\begin{array}{l}\text { Industrial structure } \\
\text { optimization effect }\end{array}$} & \multicolumn{3}{|c|}{ Foreign investment effect } \\
\hline & STRU & URB & $F D I$ & & URB \\
\hline & Model (1) & Model (2) & Model (3) & & Model (4) \\
\hline \multirow[t]{2}{*}{ GTI } & $0.0303^{\star \star \star}$ & $0.0400^{\star \star \star}$ & $0.1768^{\star \star \star}$ & $0.0294^{\star \star \star}$ & $0.0241^{\star \star \star}$ \\
\hline & $(7.32)$ & $(6.88)$ & $(12.31)$ & $(5.53)$ & (3.33) \\
\hline \multirow[t]{2}{*}{ INFRA } & $0.0012^{\star \star}$ & $0.0096^{\star \star \star}$ & $-0.0124^{\star \star \star}$ & $0.0122^{\star \star \star}$ & $0.0079^{\star \star \star}$ \\
\hline & $(2.00)$ & $(9.15)$ & $(-3.42)$ & $(12.33)$ & $(4.93)$ \\
\hline \multirow[t]{2}{*}{$E D U$} & -0.0002 & $0.0057^{\star \star \star}$ & $0.0239^{\star \star \star}$ & $0.0044^{\star \star \star}$ & $0.0048^{\star \star \star}$ \\
\hline & $(-0.85)$ & $(12.28)$ & $(11.91)$ & $(8.02)$ & $(8.07)$ \\
\hline \multirow[t]{2}{*}{ MARKET } & 0.0026 & $0.0116^{\star \star \star}$ & $0.0599^{\star \star \star}$ & $0.0071^{\star \star \star}$ & $0.0049^{*}$ \\
\hline & $(0.05)$ & $(5.63)$ & $(10.86)$ & $(4.79)$ & $(1.66)$ \\
\hline \multirow[t]{2}{*}{ FIN } & $0.0251^{\star \star \star}$ & $0.0505^{\star \star \star}$ & 0.0153 & $0.0667^{\star \star \star}$ & 0.0201 \\
\hline & $(6.61)$ & $(5.48)$ & $(0.76)$ & $(7.55)$ & $(1.27)$ \\
\hline \multirow[t]{2}{*}{ STRU } & & & & & 0.0011 \\
\hline & & & & & $(0.52)$ \\
\hline \multirow[t]{2}{*}{$F D I$} & & & & & $0.0026^{\star \star \star}$ \\
\hline & & & & & $(2.70)$ \\
\hline \multirow[t]{2}{*}{ ESTR } & & $0.1992^{\star \star \star}$ & & & $0.3329^{\star \star \star}$ \\
\hline & & $(4.77)$ & & & $(2.59)$ \\
\hline \multirow[t]{2}{*}{ INFOR } & & & & $0.0413^{\star * \star}$ & $0.0418^{\star \star \star}$ \\
\hline & & & & $(5.73)$ & $(4.08)$ \\
\hline \multirow[t]{2}{*}{ _cons } & 0.0036 & $0.0267^{*}$ & $-0.5712^{\star \star \star}$ & $0.0694^{\star \star \star}$ & $0.1317^{\star \star \star}$ \\
\hline & $(0.41)$ & $(1.84)$ & $(-7.72)$ & $(3.85)$ & $(4.05)$ \\
\hline$N$ & 360 & 360 & 360 & 360 & 360 \\
\hline
\end{tabular}

Note. * $* \star$ and $* \star \star$ represent significance at $10 \%, 5 \%$, and $1 \%$ level, respectively; the $t$-test is shown in () Industrial structure optimization effect. The green technology innovation has a positive but insignificant impact on industrial structure optimization (model (1) in Table 6), and industrial structure optimization plays a positive but insignificant role in promoting urbanization (model (2) in Table 6), which 
demonstrates that the mediating effect of industrial structure optimization effect on promoting urbanization development is insignificant. The empirical results are not consistent with our expectations, and the reason may be that the low-end lock of industry structure in China. It's an undoubted actuality that the economic growth model of China is still at the extensive stage, resulting in the irrational industrial structure and low-end industrial division. Meanwhile, the green technology innovation is still in development. Limited innovation fails to the optimization of industrial structure. As a result, the positive mechanism of industrial structure optimization in promoting urbanization development has not been fully demonstrated.

Foreign investment effect. Green technology innovation has remarkably enhanced the foreign investment level (model (3) in Table 6), and the foreign investment plays a significant positive role in promoting urbanization (model (4) in Table 6), which indicates that green technology innovation is conducive to the improvement of foreign investment level, thus promoting urbanization development. Hence, the mediating effect of foreign investment effect on promoting urbanization development is notable. On one hand, with the weakening of labor dividends, the cost-seeking foreign investment in China is gradually transferring (Li et al. 2016). The green technology innovation provides technical support for the improvement of investment environment, thus increasing the attraction to foreign direct investment. On the other hand, foreign investment structure in China has been continuously optimized. In 2017, the actual absorption of foreign capital in China's high-tech industries increased by $61.7 \%$ year-on-year, accounting for $28.6 \%, 9.5$ percentage points higher than the same period last year (Wang 2018). The knowledge spillover effect and structural optimization effect caused by the improvement of the quality of foreign investment further promote the improvement of urbanization.

Energy consumption effect. Green technology innovation has a significant impact on energy consumption structure optimization (model (5) in Table 6), and the energy consumption structure optimization has remarkably promoted the urbanization level (model (6) in Table 6), which indicates that green technology innovation is helpful to the upgrading of energy consumption structure, thus promoting urbanization level. Therefore, the mediating effect of energy consumption effect promotes urbanization development. On one hand, green technology improves the efficiency of tackling environmental pollution caused by energy consumption. On the other hand, green technology innovation widens the use of clean energy such as natural gas. In recent years, China's coal-based energy consumption structure has been greatly optimized. The proportion of clean energy consumption represented by natural gas has been rising, with natural gas accounting for $7.92 \%$ of total energy consumption in 2019 , up from $2.5 \%$ in 2005 . Energy consumption structure optimization can alleviate pollution emissions and improve the quality of economic growth, so as to provide effective guarantee for the construction of urbanization.

Informatization development effect. Green technology innovation has significantly increased the informatization development level (model (7) in Table 6), and the informatization development has remarkably promoted the urbanization level (model (8) in Table 6), which demonstrates that the mediating effect of informatization development effect on promoting urbanization development is significant. The development of green technology leads to the flourish of the information industries such

Page 18/26 
as 5G, cloud computing, big data and artificial intelligence in China, which is conducive to the integration of digital economy and real economy, together with the development of smart city. At the same time, the development of smart livelihood, smart government, and smart transportation further stimulates the demand for information consumption, forming a virtuous circle of mutual benefit development of informatization and urbanization.

Furthermore, the model (9) in Table 6 is the estimated result of incorporating intervening variables in the same equation. The coefficient of $G T /$ is 0.0241 , smaller than that in the model (6) in Table 4, which further indicates that the indirect effect of green technology innovation on urbanization is notable. That is to say, green technology innovation has indirectly accelerated the construction of urbanization by attracting foreign investment, optimizing the structure of energy consumption and promoting the development of informatization, which indicates that the Hypothesis 3 is verified.

\section{Conclusions And Policy Implications}

Green technology innovation not only directly promotes the development of urbanization but also exerts a significant intermediary impact on urbanization by influencing a country's foreign investment, energy consumption structure and informationalized level. This paper investigates the direct and indirect impact of green technology innovation on urbanization based on the data of 30 Chinese provinces from 2005 to 2016. Firstly, the direct impact of green technology innovation on urbanization is analyzed through the FGLS estimation method. Secondly, urbanization is divided into three dimensions, namely population urbanization, industrial urbanization and ecological urbanization, and the impact of green technology innovation on them are respectively measured by applying FGLS method. Finally, the indirect impact of green technology innovation on urbanization is examined based on the mediating effect method. The main conclusions are briefly summarized as follows.

The results demonstrate the evidence that green technology innovation directly promotes the development of urbanization in China. Moreover, green technology innovation has significant positive effects on population urbanization, industrial urbanization, especially ecological urbanization. These findings are understandable because that green technology innovation aims at environmental friendliness and economic development. On one hand, environmental pollution problems in the development of urbanization can be alleviated through innovative technologies, achieving the green application of green innovative results and further the development of ecological urbanization. On the other hand, the introduction of technological innovation mode stimulates economic growth and raises the level of residents' income, so as to improve the development of population urbanization. In addition, the high-tech industrial system is well established based on the industrialization and marketization of green technology innovation, which drives the improvement of industrial urbanization. The comprehensive impact of green technology innovation on population urbanization, industrial urbanization and ecological urbanization makes it more effective in promoting the development of urbanization. Therefore, attention should be paid to improving the introduction mechanism of high-end technical talents, which will contribute to the concentration of innovation resources. Meanwhile, it is necessary to formulate 
urbanization policies that optimize the environment for innovation, such as expanding the financing mechanism channels and strengthening the legal guarantee of green technology innovation, thus improving the efficiency of green technology innovation and promoting urbanization development.

This paper also reveals the indirect impact of green technology innovation on urbanization. From a detail standpoint, foreign investment, energy consumption structure and informatization development have significant intermediary effects in the indirect relationship between green technology innovation and urbanization, while the intermediary effect of industrial structure is not significant. A possible explanation for this is that the transition chain of green technology from productization to industrialization is relatively weak at the initial stage, and the path dependence of traditional industries hinders the further development of green industries. That is, the non-significant impact of green technology innovation on industrial structure upgrading leads to the ineffectiveness of the mediating effect of industrial structure optimization between green technology innovation and urbanization. Hence, effective industrial upgrading policies should be implemented as soon as possible. For example, vigorously develop modern service industry and happiness industries, coordinate government resources to promote green industries, and construct industrial parks, which is conducive to realizing the "city-industry integration" of urbanization development. Besides, the positive effect of foreign investment, energy consumption structure and informatization development should also be taken into account. Local government should greatly relax market access for foreign investment, ensure the steady supply of clean energy and stimulate its consumption demand, and promote smart city construction with market as the orientation.

Our findings, especially the mechanism through which green technology innovation affects urbanization, may be of significant practical utility to policymakers. Identifying the driving elements of urbanization development allows cities to evolve towards a sustainable development, by structuring feasible and realistic urbanization policies. Besides, owing to the data limitations, the analysis of the effect of green technology innovation is simply based on the provincial data. It is necessary to conduct a deepen research on the mechanism of green technology innovation at the city level, which will help to provide more targeted urbanization policy implications.

\section{Declarations}

\section{Ethics approval and consent to participate}

Not applicable.

\section{Consent for publication}

Not applicable.

\section{Availability of data and materials}

The datasets used and/or analysed during the current study are available from the corresponding author on reasonable request. 
Coompeting interests

The authors declare that they have no completing interests.

\section{Funding}

This study was supported by the Key Project of National Social Science Fund of China (Grant No. 19AJY011), the Major Project of Jiangsu's Social Science Fund (Grant No. 21ZD005), scientific Research Fund for the Fifth Phase of "333 High-level Talent Training Project" of Jiangsu Province in 2020 (Grant No. BRA2020106), and the Major Project of Nanjing's Social Science Fund (Grant No. 21ZD02).

\section{Author Contributions}

Yingzhi Xu and Ruijie Zhang provided the article's ideas, methods and the framework of the whole study; Ruijie Zhang was responsible for model research and English text content; Xiaomin Fan was responsible for English text content and polish; Qiutong Wang was responsible for the consolidation of data and specific writing of the article content.

\section{Acknowledgments}

We express sincere gratitude to the potential reviewers for their help to improve the quality of the manuscript.

\section{References}

1. Bettencourt LMA, Lobo J, Helbing D, Kühnert C, West GB (2007) Growth, innovation, scaling, and the pace of life in cities. Proc Natl Acad Sci 104(17):7301-7306. https://doi.org/10.1073/pnas.0610172104.

2. Brezis ES, Krugman PR, Tsiddon D (1993) Leapfrogging in international competition: A theory of cycles in national technological leadership. Am Econ Rev 83(5):1211-1219. https://www.jstor.org/stable/2117557.

3. Buhaug $\mathrm{H}$, Urdal $\mathrm{H}$ (2013) An urbanization bomb? Population growth and social disorder in cities. Glob Environ Chang 23(1):1-10. https://doi.org/10.1016/j.gloenvcha.2012.10.016.

4. Cai H, Xu Y (2017) Does the opening up of trade affect the upgrading of China's industrial structure? J Quant Techn Econ 34(10):3-22. (in Chinese)

5. Carlino GA, Chatterjee S, Hunt RM (2007) Urban density and the rate of invention. J Urban Econ 61(3):389-419. https://doi.org/10.1016/j.jue.2006.08.003.

6. Chen W, Ding W (2015) A Preliminary Study of Green Technology Innovation in the Construction of Urbanization. J Cent South Univ For Techno 9(30):40-43. (in Chinese)

7. Chenery H, Syrquin M (1975) Patterns of development: 1950-1970. Oxford University Press New York 
8. Cohen B (2005) Urbanization in developing countries: Current trends, future projections, and key challenges for sustainability. Technol Soc 28:63-80. https://doi.org/10.1016/j.techsoc.2005.10.005.

9. Cobbinah PB, Erdiaw-Kwasie MO, Amoateng P (2015a) Rethinking sustainable development within the framework of poverty and urbanisation in developing countries. Environ Dev 13:18-32. https://doi.org/10.1016/j.envdev.2014.11.001.

10. Cobbinah PB, Erdiaw-Kwasie MO, Amoateng P (2015b) Africa's urbanisation: Implications for sustainable development. Cities 47:62-72. https://doi.org/10.1016/j.cities.2015.03.013.

11. Driessen, P.H., Hillebrand, B., Kok, R.A.W., and Verhallen, T.M.M. (2013). Green new product development: the pivotal role of product greenness. Transactions on Engineering Management, 60(02):315-326. https://doi.org/10.1109/TEM.2013.2246792

12. Fan $G$, Wang $X$, Ma G (2011) The contribution of China's marketization process to economic growth. Econ Res 9(283):1997-2011. (in Chinese)

13. Gan D (2014) Research on countermeasures of coordinated development of scientific and technological innovation and new urbanization. Sci Technol Prog Policy 31(6):41-45. (in Chinese)

14. Guo R, Lv S, Liao T, Xi F, Zhang J, Zuo X, Cao X, Fng Z, Zhang Y (2020) Classifying green technologies for sustainable innovation and investment. Res Conserv Re 153:104580. (in Chinese)

15. Guo Y, Zhu J, Liu X (2018) Implication of rural urbanization with place-based entitlement for social inequality in China. Cities 82:77-85. https://doi.org/10.1016/j.cities.2018.05.007.

16. Krey V, O'Neill BC, Ruijven BV, Chaturvdi V, Daioglou V, Eom J, Jiang L, Nagai Y, Pachauri S, Ren X (2012) Urban and rural energy use and carbon dioxide emissions in Asia. Energy Econ 34:S272S283. https://doi.org/10.1016/j.eneco.2012.04.013.

17. Kuang B, Lu X, Han J, Fan X, Zuo J (2020) How urbanization influence urban land consumption intensity: Evidence from China. Habitat Int 100:e102103. https://doi.org/10.1016/j.habitatint.2019.102103.

18. Lee SH, Park S, Kim T (2015) Review on investment direction of green technology R\&D in Korea. Renew Sustain Energy Rev 50:186-193. https://doi.org/10.1016/j.rser.2015.04.158.

19. Li K (2012) Study the spirit of the 18th National Congress of the Communist Party of China to promote sustained and sound economic development and social progress http://cpc.people.com.cn/n/2012/1121/c64094-19643712.html (Accessed 6 August 2021)

20. Li Y, Jia L, Wu W, Yan K, Liu Y (2018) Urbanization for rural sustainability - Rethinking China's urbanization strategy. J Clean Prod 178:580-586. https://doi.org/10.1016/j.jclepro.2017.12.273.

21. Li Y, Liu X, Yang L (2016) Divestment of foreign-funded enterprises: motivation and impact mechanism -- based on the empirical analysis of the questionnaire survey in 10 cities in the east coast. Manag World (4):37-51. (in Chinese)

22. Liang L, Wang Z, Li J (2019) The effect of urbanization on environmental pollution in rapidly developing urban agglomerations. J Clean Prod 237:e117649. https://doi.org/10.1016/j.jclepro.2019.117649. 
23. Lin X, Wang D, Ren W, Liu Y (2013) Research on the mechanism of urbanization on economic development in China. Geogr Res 32(04):691-700. (in Chinese)

24. Liu Y, Yuan X, Ye Y (2016) Interactive effects and paths between informatization and new urbanization. Urban Probl 6:24-32. (in Chinese)

25. Liu Z, Ding M, He C, Li J, Wu J (2019) The impairment of environmental sustainability due to rapid urbanization in the dryland region of northern China. Landsc Urban Plan 187:165-180. https://doi.org/10.1016/j.landurbplan.2018.10.020.

26. Luo L, Liang S (2016) Green technology innovation efficiency and factor decomposition of China's industrial enterprises. China Popul Resour Environ 26(09):149-157

27. Luo J, Zhang X, Wu Y, Shen J, Shen L, Xing X (2018) Urban land expansion and the floating population in China: For production or for living? Cities 74:219-228.

https://doi.org/10.1016/j.cities.2017.12.007.

28. Luo Q, Miao C, Sun L, Meng X, Duan M (2019) Efficiency evaluation of green technology innovation of China's strategic emerging industries: An empirical analysis based on Malmquist-data envelopment analysis index. J Clean Prod 238:e117782. https://doi.org/10.1016/j.jclepro.2019.117782.

29. Montgomery MR (2008) The Urban Transformation of the Developing World. Sci 319:761-764. https://doi.org/10.1126/science.1153012.

30. Moomaw RL, Shatter AM (1996) Urbanization and economic development: a bias toward large cities? J Urban Econ 40:13-37. https://doi.org/10.1006/juec.1996.0021.

31. Oltra V, Saint JM (2009) Sectoral systems of environmental innovation: an application to the French automotive industry. Technol Forecasting Social Change 76(04):567-583. https://doi.org/10.1016/j.techfore.2008.03.025.

32. Peng B, Zheng C, Wei G, Elahi E (2020) The cultivation mechanism of green technology innovation in manufacturing industry: From the perspective of ecological niche. J Clean Prod 252:e119711. https://doi.org/10.1016/j.jclepro.2019.119711.

33. Qiu Y (2013) The technological innovation effect of urbanization - based on the empirical study of China's regional panel data from 1990 to 2010. Chinese J Popul Sci (1):26-35. (in Chinese)

34. Sang B, Zhang C (2018) Promote high-quality development of China's economy by foreign direct investment. Expand Horiz 4:83-88. https://doi.org/10.3969/j.issn.1006-0138.2018.04.012.

35. Shen K, Jiang R (2007) How Does Urbanization Affect Economic Growth in China. Stat Res 6:9-15. (in Chinese)

36. Song C, Liu Q, Gu S, Wang Q (2018) The impact of China's urbanization on economic growth and pollutant emissions: An empirical study based on input-output analysis. J Clean Prod 198:12891301. https://doi.org/10.1016/j.jclepro.2018.07.058.

37. Sun L, Miao C, Yang L (2017) Ecological-economic efficiency evaluation of green technology innovation in strategic emerging industries based on entropy weighted TOPSIS method. Ecol Indic 73:554-558. https://doi.org/10.1016/j.ecolind.2016.10.018. 
38. Tian Y. Zhang W. Liu M (2017) The measurement of coupling coordination degree between scientific and technological innovation and inclusive development of new urbanization -- based on the analysis of provincial data. Urban Probl (1):12-18. (in Chinese)

39. United Nations (2018) 2018 Revision of World Urbanization Prospects https://www.un.org/development/desa/publications/2018-revision-of-world-urbanizationprospects.html (Accessed 8 August 2021)

40. Wan L, Huang Z (2004) Green technology innovation: an effective way to promote the sustainable development of China's economy. Ecol Econ 6:29-31. https://doi.org/10.3969/j.issn.16714407.2004.06.005.

41. Wang K (2018) China's utilization of foreign capital increased $79 \%$ year on year in 2017 http://paper.people.com.cn/rmrbhwb/html/2018-01/17/content_1830781.htm (Accessed 6 August 2021).

42. Wu F, Shen $H$ (2013) New urbanization spatial agglomeration of innovative elements and industrial development of city clusters. J Zhongnan Univ Econ Law (4):36-42+159. (in Chinese)

43. Wu H, Hao Y, Weng J (2019) How does energy consumption affect China's urbanization? New evidence from dynamic threshold panel models. Energy Policy 127:24-38. https://doi.org/10.1016/j.enpol.2018.11.057.

44. Xu Y, Wang Q (2018) Research on the impact of energy consumption on new urbanization -- based on the threshold effect test. East China Econ Manag 32(5):5-13+2. (in Chinese)

45. Xu W, Zheng J, Liu C (2020) Environmental regulation green technology innovation and urbanization efficiency: an analysis of space measurement and threshold effect. J Zhejiang Univ Technol (Soc Sci) 19(01):31-38. (in Chinese)

46. Yang Y, Liu J, Zhang Y (2017) An analysis of the implications of China's urbanization policy for economic growth and energy consumption. J Clean Prod 161:1251-1262. https://doi.org/10.1016/j.jclepro.2017.03.207.

47. Yuan J, Lu Y, Ferrier RC, Liu Z, Su H, Meng J, Song S, Jenkins A (2018) Urbanization rural development and environmental health in China. Environ Dev 28:101-110. https://doi.org/10.1016/j.envdev.2018.10.002.

48. Zhang Q (2015) An empirical study of environmental regulations influence on green technology innovation - based on different regulation policies and 30 provinces data in China. J Ind Technol Econ 34(7):10-18. (in Chinese)

49. Zhang $Y$, Huang $B$ (2015) Research on the path of industrial structure upgrading driven by innovation. Inq Econ Issues, (3):107-112. (in Chinese)

50. Zheng Q (2017) The impact of technological innovation on new urbanization - based on the empirical analysis of panel threshold model. Urban Probl (6):25-35. (in Chinese)

\section{Figures}




\section{Green technology innovation}

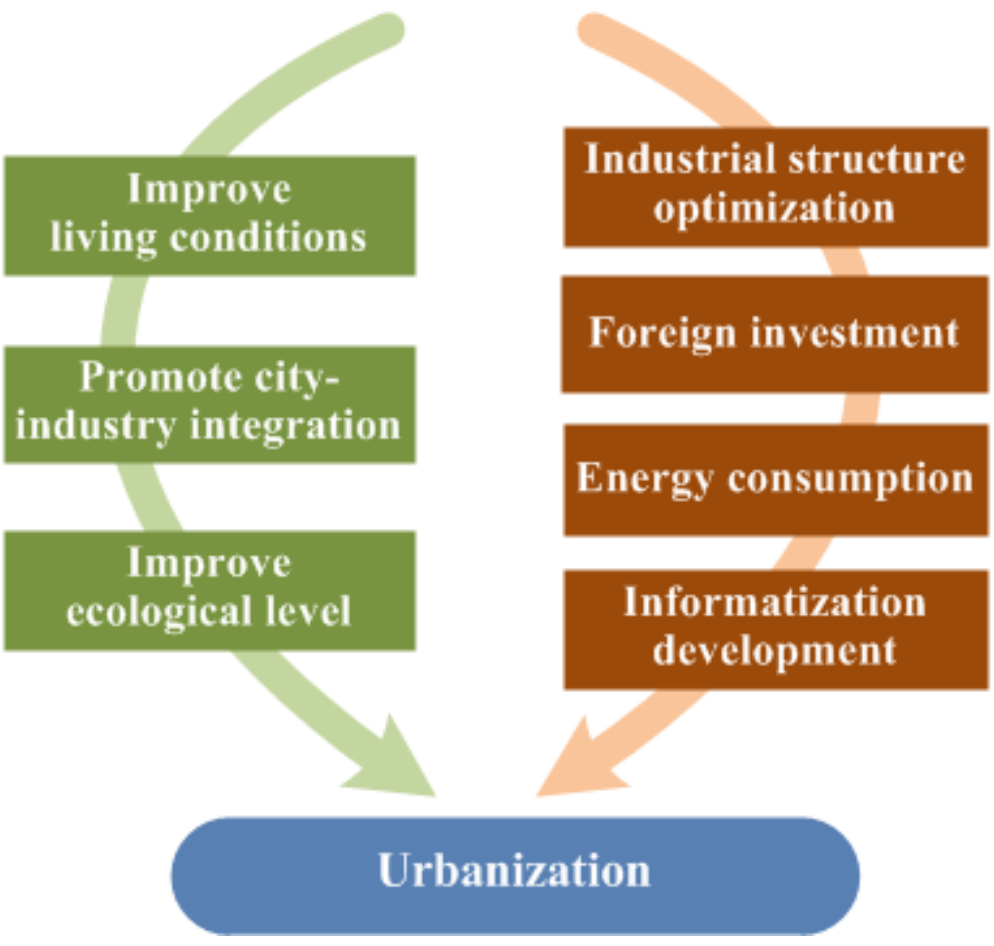

Figure 1

Impact mechanism of green technology innovation affecting urbanization 


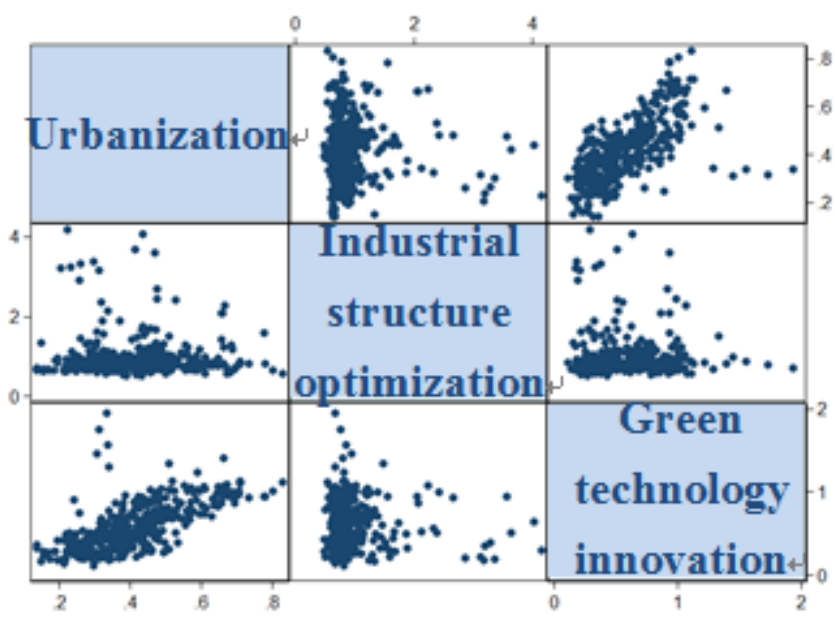

a) Industrial structure optimization effect

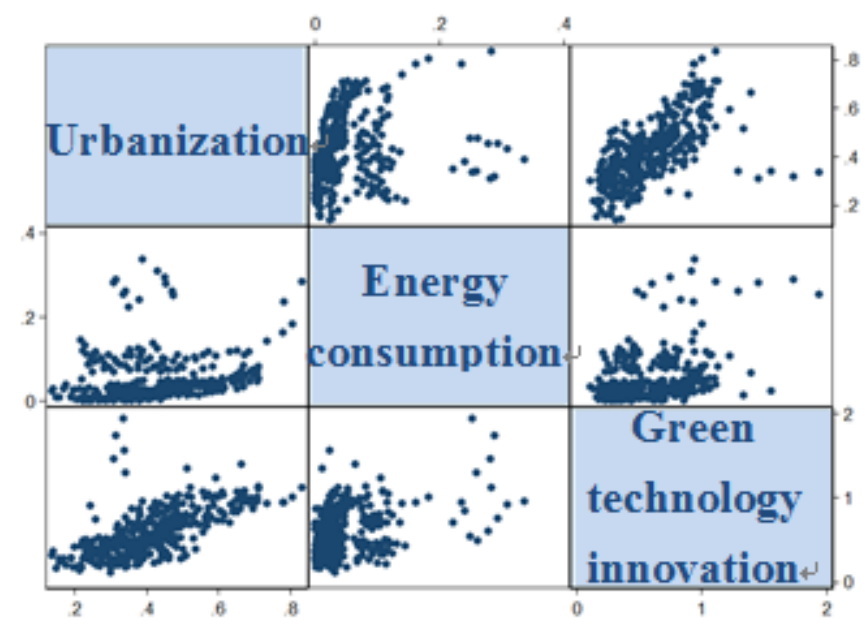

c) Energy consumption effect

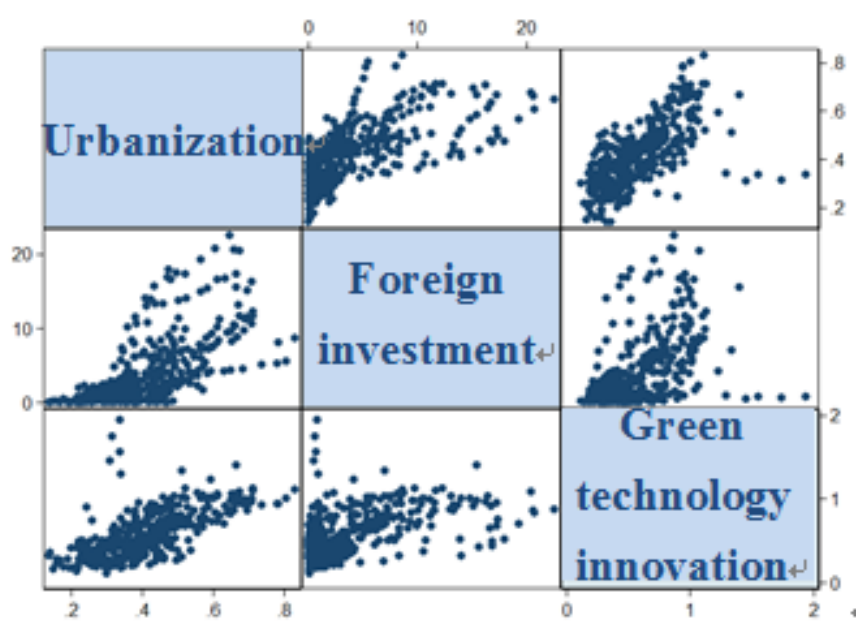

b) Foreign investment effect

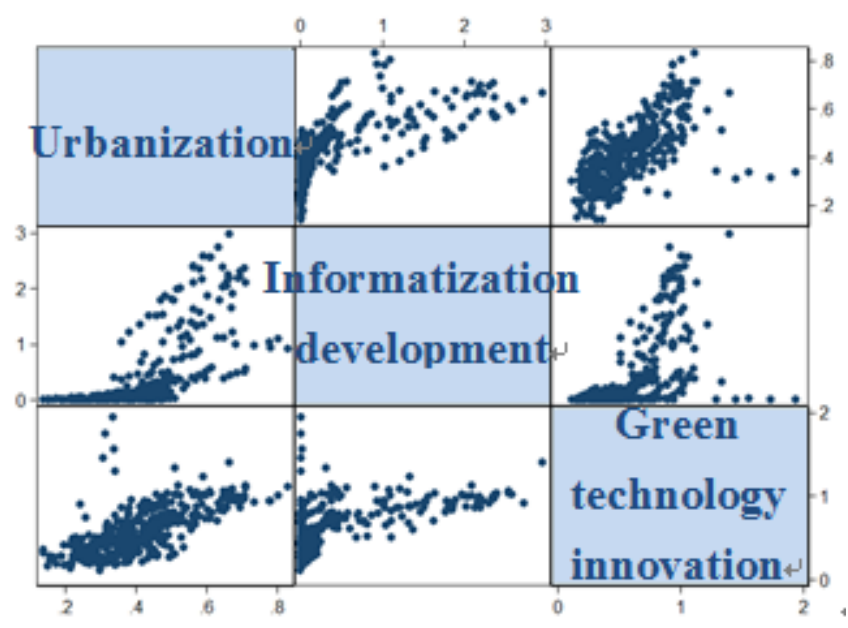

d) Informatization development effect

Figure 2

Scatter diagram of the transmission mechanism

\section{Supplementary Files}

This is a list of supplementary files associated with this preprint. Click to download.

- GraphicalAbstract.docx 